\title{
Dampak Efikasi Diri terhadap Beban Kognitif dalam Pembelajaran Matematika dengan Emosi Akademik sebagai Mediator
}

\author{
Sunawan ${ }^{1}$, Sugesti Yoan Ahmad Yani ${ }^{2}$, Trubus Inggariani Kencana ${ }^{3}$, \\ Catharina Tri Anna ${ }^{4}$, Mulawarman $^{5}$, Afriyadi Sofyan ${ }^{6}$
}

1,2,3,4,5,6Jurusan Bimbingan Konseling FIP Universitas Negeri Semarang

\begin{abstract}
The purpose of present study was to identify the role of academic emotions in mediating the correlation between self-efficacy and cognitive load in mathematics learning. Four hundred and eighty-seven high school students (191 boys and 296 girls) were involved in the correlational study. Structural equation modelling, in particular mediation analysis, was applied to identify the mediation effect of academic emotions. The results showed that selfefficacy predicted academic emotions (namely enjoyment, anger, and boredom directly, but anxiety indirectly). Then, academic emotions predicted cognitive load: extraneous load was predicted by enjoyment, anger, and boredom; intrinsic load was predicted by enjoyment and anxiety; whereas germane load was only predicted by enjoyment. Enjoyment negatively mediated self-efficacy with extraneous load, but positively mediated self-efficacy with intrinsic and germane load. Anger negatively mediated self-efficacy with extraneous load. Boredom negatively mediated extraneous and intrinsic load. Findings of present study clarify the role of academic emotions on cognitive performance, particularly cognitive load.
\end{abstract}

Keywords: academic emotions; cognitive load; self-efficacy

Abstrak. Penelitian ini bertujuan untuk mengidentifikasi peran emosi akademik dalam memediasi hubungan antara efikasi diri dan beban kognitif dalam pembelajaran matematika. Sebanyak 487 siswa (191 laki-laki dan 296 perempuan) terlibat dalam studi korelasional ini. Teknik analisis mediasi dalam structural equation modelling digunakan untuk mengidentifikasi peran emosi akademik. Hasil penelitian menunjukkan bahwa efikasi diri memprediksi emosi akademik (yakni kesenangan, kemarahan, dan kebosanan secara langsung, serta kecemasan secara tidak langsung). Selanjutnya emosi akademik memprediksi beban kognitif: di mana extraneous load diprediksi oleh kesenangan, kemarahan, dan kebosanan; intrinsic load diprediksi oleh kesenangan dan kecemasan, sedangan germane load hanya diprediksi kesenangan saja. Kesenangan memediasi efikasi diri dengan extraneous load secara negatif, tetapi memediasi efikasi diri dengan intrinsic dan germane load secara positif. Kemarahan memediasi efikasi diri dengan extraneous load secara negatif. Kebosanan memediasi efikasi diri dengan extraneous dan intrinsic load secara negatif. Temuan penelitian ini mempertegas peran emosi akademik terhadap kinerja kognitif, khususnya beban kognitif.

Kata kunci: beban kognitif; emosi akademik; efikasi diri

Memori jangka pendek atau memori kerja memiliki kapasitas memproses informasi

\footnotetext{
${ }^{1}$ Korespondensi mengenai artikel ini dapat melalui: sunawan@mail.unnes.ac.id
}

dan pengetahuan secara terbatas. Memori jangka pendek hanya dapat memproses informasi sebanyak tujuh unit dan kurang lebih 2 unit, dan terdapat dua sub-sistem memori jangka pendek yang diarahkan 
untuk memproses informasi yang berupa visual dan auditori (Kalyuga, 2009). Keterbatasan memori jangka pendek mengisyaratkan bahwa tidak semua informasi yang ditangkap indra akan terproses secara memadai dalam memori jangka pendek.

Dalam konteks pembelajaran di kelas, kapasitas memori jangka pendek penting untuk dioptimalkan guna memproses pengetahuan dan informasi yang relevan dan terkait dengan konten pembelajaran. Menurut teori beban kognitif (cognitive load theory), penggunaan memori jangka pendek optimal jika guru mampu menurunkan jumlah extraneous load, mengelola intrinsic load menjadi unit-unit informasi yang mudah dicerna, dan mendorong peningkatan germane load (Clark, Nguyen, \& Sweller, 2006). Intrinsic load merupakan beban kognitif yang bersumber dari kompleksitas informasi yang diproses, extraneous load merupakan beban kognitif yang berasal dari metode instruksional yang tidak relevan dengan materi pelajaran, sementara germane load merupakan beban kognitif yang muncul dalam usaha untuk memahami atau menguasai materi (Sweller, 2010ab).

Meskipun teori beban kognitif mampu memberikan implikasi yang jelas bagi praksis pembelajaran (Clark, Nguyen, \& Sweller, 2006), tetapi penelitian tentang beban kognitif saat ini masih berfokus pada proses kognitif baik dalam konteks pembelajaran konvensional di kelas maupun pembelajaran berbasis media baik melalui web maupun multimedia (Plass, Moreno, \& Brunken, 2010). Padahal, lebih lanjut penulis tersebut menjelaskan bahwa beban kognitif perlu dikaitkan dengan faktor non-kognitif, termasuk motivasi dan emosi. Oleh karena itu, penelitian ini dimaksudkan untuk mengeksplorasi dampak efikasi diri terhadap beban kognitif.
Guna memahami peran emosi akademik, maka dalam penelitian ini emosi akademik diposisikan sebagai mediator antara efikasi diri dan beban kognitif. Hasil penelitian ini diharapkan dapat memperjelas peran faktor efikasi diri dan emosi akademik terhadap beban kognitif dalam kegiatan pembelajaran matematika di kelas.

Emosi akademik merupakan emosi yang muncul selama siswa mengikuti proses pembelajaran. Pekrun (2006) secara spesifik mengelompokkan emosi menjadi activity emotion yakni emosi yang muncul seiring dengan kegiatan belajar seperti kesenangan, kebosanan, marah, dan lainlain; prospective outcome emotions yakni emosi yang berkaitan dengan prediksi tentang hasil belajar seperti kecemasan, penuh harapan, dan lain-lain; dan retrospective outcome emotions yakni emosi yang berkaitan dengan hasil belajar yang telah dicapai seperti malu, bangga, senang, dan lain-lain. Terkait dengan klasifikasi tersebut, penelitian ini fokus pada kesenangan (enjoyment), marah (anger), kejenuhan (boredom), dan kecemasan (anxiety). Hal ini dikarenakan keempat emosi tersebut merupakan jenis emosi yang sering muncul dalam konteks pembelajaran di kelas (Pekrun, Goetz, Titz, \& Perry, 2002).

Emosi akademik pada beberapa penelitian terdahulu diketahui memprediksi beban kognitif. Hasil penelitian Chen dan Chang (2009) dalam pembelajaran Bahasa Inggris menunjukkan bahwa kecemasan memprediksi secara negatif beban kognitif. Di samping itu, menurut hasil penelitian yang dilakukan Fraser dan lain-lain (2012) menunjukkan bahwa emosi positif berhubungan secara negatif dengan beban kognitif, sementara emosi negatif berhubungan secara positif dengan beban kognitif. Sayangnya, kedua penelitian tersebut mengukur beban kognitif 
sebagai konstruk tunggal dan sampai saat ini belum ada studi yang mengkorelasikan berbagai jenis emosi dengan tiga macam beban kognitif. Penelitian ini diharapkan dapat mempertegas prediksi emosi terhadap setiap jenis beban kognitif dalam konteks pembelajaran klasikal.

Di sisi lain, efikasi diri atau keyakinan individual akan kemampuannya dalam menyelesaikan suatu jenis tugas tertentu (Bandura, 1997) diketahui memprediksi emosi akademik. Hasil penelitian yang dilakukan Putwain, Sander dan Larkin (2013) menunjukkan bahwa efikasi diri memprediksi secara positif kesenangan dan memprediksi secara negatif ketidaksenangan para partisipan dalam mempelajari konten pelajaran. Penelitian lain yang dilakukan oleh Pekrun, Goetz, Frentzel, Barchfeld, dan Perry (2011) menunjukkan bahwa efikasi diri memprediksi secara positif kesenangan, namun memprediksi kemarahan, kecemasan dan kebosanan secara negatif. Marchand dan Guatierrez (2012) menyatakan bahwa efikasi diri cenderung konsisten dalam memprediksi emosi baik dalam konteks pembelajaran tradisional atau klasikal dan online.

Prediksi efikasi diri terhadap beban kognitif yang dimediasi oleh emosi akademik selaras dengan control-value of academic emotions theory yang dikembangkan oleh Pekrun (2006). Dalam teori tersebut dijelaskan bahwa dampak efikasi diri terhadap emosi akademik terjadi melalui proses appraisal, dimana efikasi diri merupakan operasionalisasi dari komponen kontrol dari proses appraisal. Selanjutnya, emosi akademik berpengaruh terhadap kinerja individu dalam memanfaatkan sumber daya kognitif (cognitive resources) dan, pada gilirannya, berpengaruh terhadap prestasi belajar (Alsa, Haq,
Siregar, Kusumaningrum, Utami, \& Bachria, 2015).

Berdasarkan paparan di atas, maka dapat diajukan hipotesis: (1) efikasi diri memprediksi secara positif kesenangan (1a), dan memprediksi secara negatif kemarahan (1b), kecemasan (1c), dan kebosanan (1d); (2) emosi akademik memprediksi beban kognitif, di mana kesenangan, kemarahan, kecemasan, dan kebosanan memprediksi secara positif intrinsic load (2a), sementara kesenangan memprediksi secara negatif extraneous load dan kemarahan, kecemasan dan kebosanan memprediksi secara positif extraneous load (2b), adapun kesenangan memprediksi secara positif germane load, tetapi kemarahan, kecemasan dan kebosanan memprediksi secara negatif germane load (2c); akhirnya, kesenangan, kemarahan, kecemasan dan kebosanan merupakan mediator terhadap efikasi diri dan beban kognitif.

\section{Metode}

Sampel penelitian yang terlibat dalam penelitian ini berjumlah 487 siswa(191 lakilaki dan 296 perempuan) yang berasal dari lima Sekolah Menengah Atas Negeri dari Kota dan Kabupaten Semarang. Partisipan diseleksi dengan menggunakan teknik cluster random sampling.

Terdapat tiga skala yang digunakan dalam penelitian, yakni skala beban kognitif, skala emosi akademik, dan skala efikasi diri. Skala yang digunakan dalam penelitian ini diadaptasi dari instrumen yang telah dipublikasikan. Oleh karenanya, prosedur back-translation diterapkan untuk keperluan adaptasi semua skala yang digunakan dalam penelitian ini.

Estimasi validitas dan reliabilitas dikenakan terhadap setiap aspek skala. Validitas skala diestimasi dengan meng- 
gunakan teknik analisis faktor eksploratori, sedangkan koefisien reliabilitas diestimasi dengan menggunakan teknik alpha. Hasil estimasi validitas dan reliabilitas semua skala dapat diperiksa dalam Tabel 1.

Beban kognitif diukur menggunakan Skala Beban Kognitif yang diadaptasi dari Cognitive Load Questionnaire yang dikembangkan oleh Leppink, Paas, Gog, dan Marrienboer (2014). Skala Beban Kognitif terdiri atas 12 butir dengan 7 skala $(1=$ sangat rendah sampai $7=$ sangat tinggi). Sebanyak 4 butir (Isi dalam pembelajaran matematika sangat kompleks) untuk mengukur intrinsic load, 4 butir (Penjelasan dan perintah dalam pembelajaran matematika sangat tidak jelas) untuk mengukur extraneous load, dan 4 butir (Pembelajaran matematika benar-benar meningkatkan pemahaman saya tentang materi matematika) untuk mengukur germane load. Studi yang dilakukan Leppink et al. menunjukkan bahwa koefisien reliabilitas Cognitive Load Questionnaire berkisar antara 0,632 sampai 0,933 .

Berdasarkan Tabel 1 dapat diketahui bahwa skala beban kognitif memiliki koefisien reliabilitas yang baik. Aspek intrinsic load memiliki koefisien reliabilitas sebesar 0,792, aspek extraneous load memiliki koefisien reliabilitas sebesar 0,897, sedangkan aspek germane load memiliki koefisien reliabilitas sebesar 0,888 . Hasil uji analisis faktor menunjukkan bahwa semua butir dalam skala beban kognitif memiliki aitem loading yang memadai atau di atas 0,500. Aspek intrinsic load memiliki rentang aitem loading antara 0,629 sampai 0,876. Aspek extraneous load memiliki rentang aitem loading sebesar 0,812 sampai 0,906 . Adapun aspek germane load memiliki aitem loading antara 0,844 sampai 0,890. Butir-butir dari aspek intrinsic load, extraneous load, dan germane load secara berturut-turut menjelaskan varians sebesar $63 \%, 76 \%$, dan $75 \%$.

Emosi akademik siswa diukur menggunakan Skala Emosi Akademik yang diadaptasi dari Academic Emotions Questionnaire (AEQ) yang dikembangkan Pekrun, Goetz, Titz, dan Perry (2002). Sebanyak 25 butir digunakan untuk mengukur empat jenis emosi selama mengikuti pembelajaran di kelas; 4 butir (Saya senang berada di kelas) untuk mengukur kesenangan, 5 butir (Saya merasa frustrasi di dalam kelas) untuk mengukur kemarahan, 5 butir (Saya merasa nerves di dalam kelas) untuk mengukur kecemasan, dan 11 butir (Saya bosan) untuk mengukur kebosanan. Skala ini memiliki 7 tingkatan penskalaan yang dimulai dari 1 (Sangat tidak sesuai) sampai 7 (Sangat sesuai). Koefisien reliabilitas berkisar dari 0,778

Tabel 1

Jumlah butir, reliabilitas, dan hasil analisis faktor eksploratori

\begin{tabular}{clcccc}
\hline No & Variabel & Jumlah Butir & $\boldsymbol{\alpha}$ & Rentang item loading & \% variance \\
\hline 1 & Efikasi diri & 8 & 0,855 & $0,609-0,795$ & 50,230 \\
2 & Kesenangan & 4 & 0,778 & $0,734-0,817$ & 60,227 \\
3 & Kemarahan & 5 & 0,814 & $0,714-0,823$ & 57,890 \\
4 & Kecemasan & 5 & 0,780 & $0,661-0,802$ & 53,952 \\
5 & Kebosanan & 11 & 0,932 & $0,714-0,819$ & 59,804 \\
6 & Intrinsic load & 4 & 0,792 & $0,629-0,876$ & 63,002 \\
7 & Extraneous load & 4 & 0,897 & $0,812-0,906$ & 76,742 \\
8 & Germane load & 4 & 0,888 & $0,844-0,890$ & 75,165 \\
\hline
\end{tabular}


sampai dengan 0,932 .

Hasil pengujian skala emosi akademik dalam penelitian ini, sebagaimana tampak pada Tabel 1, menunjukkan bahwa skala tersebut memiliki koefisien validitas dan reliabilitas yang memuaskan. Aspek kesenangan memiliki koefisien reliabilitas sebesar 0,778, kemarahan memiliki koefisien reliabilitas sebesar 0,772, kecemasan memiliki koefisien reliabilitas sebesar 0,780, sedangkan kebosanan memiliki koefisien reliabilitas yang tertinggi yakni sebesar 0,920 .

Hasil uji analisis faktor menunjukkan bahwa semua butir memiliki aitem loading di atas 0,500. Aspek kesenangan memiliki rentang aitem loading antara 0,734 sampai 0,817 dan dijelaskan sebesar 60,227\%. Aspek kemarahan memiliki rentang aitem loading antara 0,718 sampai 0,764 dan dijelaskan sebesar 52,932\%. Aspek kecemasan memiliki rentang aitem loading antara 0,661 sampai 0,802 dan dijelaskan sebesar 53,952\%. Sementara aspek kebosanan memiliki rentang aitem loading antara 0,505 sampai 0,824 dan variansnya dijelaskan sebesar $58,571 \%$.

Efikasi diri siswa diukur dengan menggunakan Skala Efikasi Diri yang diadopsi dari komponen Self Efficacy of Learning and Performance dari Motivation and Learning Strategies Questionnaire (MLSQ) yang dikembangkan oleh Pintrich et al. (1991). Skala Efikasi Diri terdiri atas 8 butir (Saya yakin akan menerima nilai sempurna dari kelas ini) dengan 7 tingkat penskalaan yang dimulai dari 1 (Sangat tidak sesuai) sampai 7 (Sangat sesuai). Koefisien reliabilitas sebesar 0,855. Rentang aitem loading dari butir-butir skala ini antara 0,609 sampai 0,795. Adapun semua butir dalam skala efikasi diri mampu menjelaskan aspek efikasi diri sebesar $50,230 \%$.
Prosedur pengumpulan dan analisis data

Proses penelitian diawali dengan mengumpulkan informed consent dari siswa yang menjadi partisipan. Pengumpulan data dilakukan saat jam pelajaran dengan meminta siswa mengisi tiga skala, yakni skala beban kognitif, skala emosi akademik, dan skala efikasi diri. Jawaban siswa yang terkumpul selanjutnya ditabulasi dan dianalisis. Keterlibatan siswa dalam menjadi partisipan bersifat sukarela. Oleh karenanya, sebelum pengumpulan data dilaksanakan, terlebih dahulu para siswa diminta untuk mengisi formulir persetujuan (informed consent) untuk menjadi partisipan dalam penelitian ini.

Analisis data dilakukan dalam dua tahap, yakni analisis Structural Equation Modelling (SEM) (Byrne, 2010) dan analisis mediasi (MacKinnon, 2008). Semua proses analisis data dilakukan dengan menggunakan perangkat lunak AMOS versi 21. Kriteria-kriteria yang digunakan untuk menilai tingkat fit model adalah: hasil uji kai kuadrat $\left(\chi^{2}\right)$, perbandingan kai kuadrat dengan derajat kebebasan atau $\mathrm{db}\left(\chi^{2} / \mathrm{db}\right)$, Comparative Fit Index (CFI), Root Mean Square Error Approximation (RMSEA), dan Standardized Root Mean Square Residual (SRMR) (Cheung \& Rensvold, 2002).

Analisis mediasi dilakukan untuk mengetahui dampak tidak langsung dari emosi akademik. Analisis ini dilakukan dengan menggunakan bias-corrected bootstrapping untuk menggeneralisir interval kepercayaan (confidence interval) (Preacher \& Hayes, 2008) yang digunakan untuk mengatasi masalah bias yang dihasilkan dari distribusi sampling yang tidak normal dari efek tidak langsung. Efek mediasi atau tidak langsung diestimasi dengan menggunakan estimasi poin dan interval kepercayaan 95\%. Estimasi poin dianggap signifikan jika interval kepercayaan tidak berisi nol. 


\section{Hasil}

\section{Diskripsi data}

Tingkat rata-rata dan SD setiap variabel dalam penelitian ini dan hubungan antar semua variabel dapat dilihat dalam matriks interkorelasi sebagaimana disajikan dalam Tabel 2. Dilihat dari rata-rata, para siswa cenderung memiliki kondisi emosi akademik senang dalam mengikuti pembelajaran matematika. Adapun emosi kemarahan, kecemasan dan kebosanan dalam mengikuti pembelajaran matematika relatif lebih rendah dibandingkan dengan kesenangan. Tingkat kesenangan siswa dalam mengikuti pembelajaran matematika hampir mencapai tinggi, sedangkan tingkat kemarahan, kecemasan dan kebosanan siswa cenderung berada pada posisi sedang. Di sisi cognitive load, para siswa cenderung menggunakan germane load lebih tinggi dibandingkan dengan instrinsic dan extraneous load.

Tabel 2 menunjukkan bahwa secara umum terdapat hubungan antara efikasi diri dengan emosi akademik, serta emosi akademik dengan beban kognitif. Kesenangan berhubungan negatif dengan extraneous load, sementara kemarahan, kecemasan, dan kebosanan berhubungan negatif dengan extraneous load. Kemarahan, kecemasan dan kebosanan berhubungan positif dengan intrinsic load, sedangkan hanya kebosanan yang berhubungan negatif dengan germane load. Efikasi diri berhubungan positif dengan kesenangan dan germane load, tetapi berhubungan negatif dengan kemarahan, kecemasan, dan kebosanan serta extraneous load.

Prediksi efikasi diri terhadap beban kognitif melalui emosi akademik

Daya prediksi efikasi terhadap beban kognitif melalui emosi akademik diuji dengan menggunakan Structural Equation Modelling (SEM) dengan teknik modelling Maximum Likelihood (ML) (Byrne, 2010). Model dapat diterima apabila nilai $\chi^{2} / \mathrm{db}$ tidak lebih dari 3, CFI di atas 0,90 atau lebih diharapkan mencapai 0,95 atau lebih, RMSEA kurang dari 0,06, dan SRMR kurang dari 0,09 (Hu \& Bentler, 1999). Hasil pengujian SEM dengan teknik Maximum Likelihood (ML), sebagaimana tampak pada tabel 3, menunjukkan bahwa model prediksi beban kognitif dari emosi akademik dan efikasi diri memiliki tingkat fit indeks yang memuaskan $\left(\chi^{2}=2030,122\right.$; $\mathrm{df}=917 ; \mathrm{p}<.01 ; \chi^{2} / \mathrm{df}=2,214 ; \mathrm{CFI}=$,909; RMSEA $=, 050$ ).

Tabel 2

Matriks interkorelasi

\begin{tabular}{|c|c|c|c|c|c|c|c|c|}
\hline & ED & Sng & Mrh & Cms & Bsn & IL & EL & GL \\
\hline Sng &, $475^{* *}$ & & & & & & & \\
\hline Mrh &,$- 247^{* *}$ &,$- 296^{* *}$ & & & & & & \\
\hline Cms &,$- 190^{* *}$ &,$- 282^{* *}$ &, $526^{* *}$ & & & & & \\
\hline Bsn &,$- 249^{* *}$ &,$- 374^{* *}$ & $536^{* *}$ &, $410^{* *}$ & & & & \\
\hline IL &,- 011 & ,009 &, $249^{* *}$ &, $255^{* *}$ &, $123^{* *}$ & & & \\
\hline EL &,$- 240^{* *}$ &,$- 282^{* *}$ &, $442^{* *}$ &, $370^{* *}$ &, $426^{* *}$ &, $303^{* *}$ & & \\
\hline GL &, $360^{* *}$ & ,439 &,- 027 & ,045 &,$- 163^{* *}$ &,$- 163^{* *}$ &, $165^{* *}$ & \\
\hline Rata-rata & 3,823 & 3,769 & 2,635 & 2,778 & 2,717 & 3,527 & 2,725 & 4,715 \\
\hline SB & 0,521 & 0,652 & 0,837 & 0,776 & 0,926 & 0,643 & 0,868 & 0,672 \\
\hline
\end{tabular}


Tabel 3

Model prediksi beban kognitif dari emosi akademik dan efikasi diri

\begin{tabular}{|c|c|c|c|}
\hline Arah Hubungan & $\beta$ & $\mathbf{t}$ & $\mathbf{r}^{2}$ \\
\hline ED $\rightarrow$ Sng & 0,621 & $8,569^{* *}$ & 0,386 \\
\hline $\mathrm{ED} \rightarrow \mathrm{Mrh}$ & $-0,364$ & $-6,422^{* *}$ & 0,133 \\
\hline $\mathrm{Mrh} \rightarrow \mathrm{Cms}$ & 0,730 & $9,068^{* *}$ & 0,533 \\
\hline $\mathrm{ED} \rightarrow \mathrm{Bsn}$ & $-0,119$ & $-2,805^{* *}$ & 0,573 \\
\hline Mrh $\rightarrow$ Bsn & 0,705 & $10,111^{* *}$ & \\
\hline Sng $\rightarrow$ IL & 0,263 & $4,606^{* *}$ & 0,117 \\
\hline $\mathrm{Cms} \rightarrow \mathrm{IL}$ & 0,193 & $3,003^{* *}$ & \\
\hline Bsn $\rightarrow$ IL & 0,127 & $2,089^{*}$ & \\
\hline Sng $\rightarrow$ EL & $-0,114$ & $-2,409^{*}$ & 0,345 \\
\hline $\mathrm{Mrh} \rightarrow \mathrm{EL}$ & 0,340 & $4,215^{* *}$ & \\
\hline Bsn $\rightarrow$ EL & 0,246 & $3,279^{* *}$ & \\
\hline Sng $\rightarrow$ GL & 0,647 & $8,493^{* *}$ & 0,418 \\
\hline
\end{tabular}

Keterangan: ED = efikasi diri; Sng = kesenangan; $\mathrm{Mrh}=$ kemarahan; $\mathrm{Cms}=$ Kecemasan; Bsn = kebosanan; IL = intrinsic load; EL = extraneous load; $\mathrm{GL}=$ germane load; ${ }^{* *} \mathrm{p}<0,01 ;{ }^{*} \mathrm{p}<$ 0,05

Sebagaimana yang diprediksi dalam hipotesis 1, efikasi diri memprediksi emosi akademik. Secara spesifik, efikasi diri memprediksi emosi kesenangan, kemarahan, dan kebosanan. Namun, emosi kecemasan tidak diprediksi efikasi diri. Selanjutnya, seperti yang diprediksi dalam hipotesis 2, emosi akademik terbukti memprediksi beban kognitif. Emosi kesenangan berhubungan dengan intrinsic load, extraneous load, dan germane load; kebosanan memprediksi efikasi diri secara sangat signifikan memprediksi intrinsic load dan extraneous load. Sementara kemarahan hanya memprediksi extraneous load, dan kecemasan memprediksi intrinsic load.

Dampak mediasi emosi akademik terhadap efikasi diri dan beban kognitif

Teknik bootstrapped bias-corrected dimplementasikan guna menguji dampak tidak langsung emosi akademi dalam menghubungkan antara efikasi diri dan beban kognitif. Dampak tidak langsung efikasi diri terhadap beban kognitif melalui emosi akademik diprediksi dalam hipotesis 3.

Hasil analisis mediasi menunjukkan bahwa emosi kesenangan, kebosanan, dan pasangan emosi kemarahan dengan kecemasan berhasil menjadi mediator bagi efikasi diri dan intrinsic load (lihat Tabel 4). Menariknya, temuan penelitian ini berhasil menunjukkan bahwa emosi kesenangan merupakan mediator yang terbaik terhadap hubungan antara efikasi diri dan intrinsic load.

Di samping itu, emosi kesenangan, kemarahan, dan kebosanan memediasi hubungan antara efikasi diri dengan extraneous load. Menariknya, baik emosi positif (kesenangan) maupun emosi negatif (kemarahan dan kebosanan) memiliki tingkat mediasi yang setara dalam menghubungkan antara efikasi diri dan extraneous load. Selanjutnya, hanya emosi kesenangan yang berhasil menjadi mediator bagi hubungan antara efikasi diri dengan germane load.

\section{Diskusi}

Penelitian ini bertujuan untuk mengidentifikasi: (1) prediksi efikasi diri terhadap emosi akademik; (2) prediksi emosi akademik terhadap beban kognitif; dan (3) peran emosi akademik dalam memediasi efikasi diri dengan beban kognitif. Temuan penelitian menunjukkan bahwa efikasi diri juga memprediksi emosi akademik dan, selanjutnya, emosi akademik memprediksi beban kognitif. 
Tabel 4

Efek mediasi emosi akademik

\begin{tabular}{|c|c|c|c|c|c|}
\hline \multirow{3}{*}{ Mediator } & \multicolumn{5}{|c|}{ Efek Mediasi yang Teramati } \\
\hline & \multirow{2}{*}{ Estimasi } & \multirow{2}{*}{ SE } & \multicolumn{3}{|c|}{ BC $95 \%$} \\
\hline & & & $\mathbf{L}$ & $\mathbf{U}$ & $\mathbf{p}$ \\
\hline \multicolumn{6}{|l|}{ Mediator antara efikasi diri dengan intrinsic load } \\
\hline $\mathrm{ED} \rightarrow \mathrm{Sng} \rightarrow \mathrm{IL}$ & ,244 & 067 & ,127 & ,395 & $<, 01$ \\
\hline $\mathrm{ED} \rightarrow \mathrm{Bsn} \rightarrow \mathrm{IL}$ &,- 023 & ,016 &,- 011 &,- 001 & $<, 05$ \\
\hline $\mathrm{ED} \rightarrow \mathrm{Mrh} \rightarrow \mathrm{Cms} \rightarrow \mathrm{IL}$ &,- 043 & ,025 &,- 100 & ,000 & $<, 05$ \\
\hline Perbedaan mediator antara Sng dan Bsn & ,266 & ,075 & ,135 & ,442 & $<, 01$ \\
\hline \multicolumn{6}{|l|}{ Mediator antara efikasi diri dengan extraneous load } \\
\hline $\mathrm{ED} \rightarrow \mathrm{Sng} \rightarrow \mathrm{EL}$ &,- 129 & ,066 &,- 264 &,- 003 & $<, 05$ \\
\hline $\mathrm{ED} \rightarrow \mathrm{Mrh} \rightarrow \mathrm{EL}$ &,- 225 & ,065 &,- 374 &,- 117 & $<, 01$ \\
\hline $\mathrm{ED} \rightarrow \mathrm{Bsn} \rightarrow \mathrm{EL}$ &,- 053 & ,028 &,- 131 &,- 012 & $<, 01$ \\
\hline $\mathrm{ED} \rightarrow \mathrm{Mrh} \rightarrow \mathrm{Bsn} \rightarrow \mathrm{EL}$ &,- 115 & 042 &,- 209 &,- 043 & $<, 01$ \\
\hline Jumlah mediasi melalui Mrh dan Bsn &,- 278 & ,057 &,- 401 &,- 181 & $<, 01$ \\
\hline Perbedaan mediator antara Mrh dan Bsn &,- 111 & 089 &,- 311 & ,056 & $>, 05$ \\
\hline Perbedaan mediator antara Sng dan Mrh+Bsn & .149 & ,092 &,- 017 & ,342 & $>, 05$ \\
\hline \multicolumn{6}{|l|}{ Mediator antara efikasi diri dengan germane load } \\
\hline $\mathrm{ED} \rightarrow \mathrm{Sng} \rightarrow \mathrm{GL}$ & ,486 & ,065 & ,366 & 621 & $<, 01$ \\
\hline
\end{tabular}

Keterangan: ED = efikasi diri; Sng = kesenangan; Mrh = kemarahan; Cms = Kecemasan; Bsn = kebosanan; IL = intrinsic load; $\mathrm{EL}=$ extraneous load; $\mathrm{GL}=$ germane load; $\mathrm{L}=$ lower level of confidance interval; $\mathrm{U}=$ upper level of confidance interval

Efikasi diri berdampak terhadap emosi akademik siswa selama mengikuti pembelajaran matematika. Siswa yang memiliki tingkat efikasi diri yang tinggi cenderung menikmati pembelajaran matematika, tetapi pada siswa yang memiliki efikasi diri yang rendah cenderung memiliki emosi kemarahan, kecemasan, dan kebosanan yang tinggi. Temuan ini selaras dengan hasil penelitian sebelumnya (Frenzel, Pekrun, \& Goetz, 2007; Luo, Ng, Lee, \& Ayee, 2016; Putwain, Sader, \& Larkin, 2013). Dampak efikasi diri terhadap emosi akademik ini selaras dengan teori control-value of academic emotions (Pekrun, 2006), di mana efikasi diri berkontribusi terhadap proses appraisal. Selanjutnya, hasil appraisal tersebut yang berdampak pada respon emosi saat mengikuti kegiatan akademik. Saat siswa meraka menilai bahwa diri-mereka mampu untuk mempelajari materi pela- jaran matematika dengan baik, maka mereka cenderung memiliki emosi yang positif dalam mempelajari matematika.

Hasil penelitian ini juga menunjukkan bahwa jenis emosi akademik tertentu berdampak terhadap beban kognitif siswa dalam mengikuti pembelajaran matematika. Kesenangan dan kecemasan memprediksi secara positif intrinsic load. Kemarahan dan kebosanan yang dialami siswa cenderung meningkatkan extraneous load siswa selama mengikuti pembelajaran matematika. Sementara kesenangan mendorong siswa untuk mengoptimalkan pemanfaatan germane load dalam mengikuti pembelajaran matematika. Penelitian sebelumnya yang dilakukan Chen dan Chang (2009) dan Fraser dan kawankawan (2012) juga menunjukkan dampak emosi akademik terhadap beban kognitif. Namun, kedua penelitian tersebut tidak membuktikan dampak emosi terhadap 
setiap jenis beban kognitif. Dengan kata lain, beban kognitif hanya diteliti sebagai konstruk tunggal. Penelitian ini berhasil menegaskan jenis emosi akademik tertentu yang berdampak terhadap setiap jenis beban kognitif.

Emosi akademik juga ditemukan mampu menghubungkan kesalingterkaitan antara efikasi diri dengan beban kognitif. Kesenangan dan kecemasan memediasi secara signifikan hubungan antara efikasi diri dengan intrinsic load. Meski kesenangan dan kecemasan mampu menjadi mediator yang signifikan, tetapi kesenangan mampu menjadi mediator yang lebih baik secara sangat signifikan dibandingkan kecemasan dalam menghubungkan antara efikasi diri dengan intrinsic load. Baik kemarahan dan kecemasan memediasi hubungan antara semua jenis efikasi dengan extraneous load. Kedua jenis emosi tersebut memiliki kemampuan memediasi hubungan efikasi diri dengan extraneous load dalam tingkatan yang sama. Adapun hubungan antara efikasi diri dengan germane load hanya dimediasi oleh kesenangan.

Hasil penelitian ini membuktikan bahwa kesenangan memiliki peran yang strategis dalam mengoptimalkan hubungan antara motivasi dengan beban kognitif. Jika dalam pembelajaran diharapkan siswa dapat mengoptimalkan germane load dan mengelola intrinsic load (Sweller, 2010ab), maka kesenangan mampu memediasi hubungan antara motivasi dengan intrinsic dan germane load secara positif. Artinya, hubungan antara efikasi diri semakin optimal ketika para siswa senang dalam menjalankan aktivitas belajar. Sebagai implikasi praktik, penting bagi guru khususnya dalam pembelajaran untuk selalu mendorong siswa mengembangkan emosi akademik yang positif, yakni kesenangan. Dengan adanya emosi senang dalam mengikuti kegiatan pembelajaran, para siswa terstimulasi untuk mengalokasikan germane load dalam porsi yang tinggi sehingga pembelajaran matematika yang diikutinya menjadi optimal.

\section{Kesimpulan}

Penelitian ini telah mengidentifikasi peran emosi akademik dalam memediasi hubungan antara efikasi diri dengan beban kognitif. Efikasi diri ditemukan memprediksi secara positif kesenangan, tetapi memprediksi secara negatif kemarahan, dan kebosanan. Selanjutnya, intrinsic load diprediksi secara positif oleh kesenangan, kecemasan dan kebosanan secara positif. Extraneous load diprediksi secara negatif oleh kesenangan, namun diprediksi secara positif oleh kemarahan dan kebosanan. Germane load hanya diprediksi oleh kesenangan secara positif.

Dampak mediasi emosi akademik terhadap efikasi diri dan beban kognitif tampak dalam penelitian ini. Hubungan antara efikasi diri dengan intrinsic load dimediasi secara positif oleh kesenangan dan dimediasi secara negatif oleh kebosanan. Demikian pula hubungan antara efikasi diri dengan extraneous load juga dimediasi secara negatif oleh kesenangan, kemarahan, dan kebosanan. Akhirnya, hanya kesenangan yang memediasi secara positif hubungan antara efikasi diri dengan germane load.

\section{Saran}

Saran bagi penelitian lanjut adalah: (a) penelitian ini merupakan penelitian yang mengkaji kesalingterkaitan antara efikasi, akademik emosi dan beban kognitif. Oleh karena itu, diharapkan hasil penelitian ini dapat dijadikan landasan bagi studi eksperimen tentang pengembangan desain pembelajaran yang mendorong siswa 
memanfaatkan sumber daya kognitif secara efektif melalui efikasi diri dan akademik emosi yang adaptif; (b) diperlukan penelitian lanjutan yang memungkinkan temuan dari penelitian ini diuji pada konteks pembelajaran online dan multimedia.

Saran bagi praktik pembelajaran matematika adalah: (a) guru matematika diharapkan untuk mendorong siswa mengembangkan efikasi diri yang tinggi selama memfasilitasi siswa mengikuti pembelajaran. Hal ini penting mengingat hasil penelitian ini menunjukkan bahwa efikasi diri yang tinggi berdampak terhadap kesenangan siswa dalam belajar mata pelajaran matematika dan, pada gilirannya, mendorong siswa memanfaatkan germane load; (b) guru matematika diharapkan senantiasa memelihara emosi kesenangan siswa dalam mengikuti pembelajaran matematika. Kesenangan memungkinkan siswa memelihara perhatiannya pada informasi yang relevan dengan tugas belajar.

\section{Kepustakaan}

Alsa, A., Haq, A. H. B., Siregar, A. J., Kusumaningrum, F. A., Utami, D., \& Bachria, R. D. (2015). Menyusun model yang efisien dan efektif dari dimensidimensi school well-being untuk memprediksi prestasi belajar matematik. Jurnal Psikologi, 42(1), 15-33.

Bandura, A. (1997). Self efficacy: The exercise of control. New York, NY: W.H. Freeman and Company.

Byrne, B. M. (2010). Structural equation modelling with AMOS: Basic concepts, applications and programming. New York, NY: Routledge.

Chen, I., \& Chang, C. (2009). Cognitive load theory: An empirical study of anxiety and task performance in language learning. Electronic Journal of Research in Educational Psychology, 7(2). 729-746.

Cheung, G. W., \& Resvold, R. B. (2002). Evaluating goodness-of-fit indexes for testing measurement invariance. Structural Equation Modelling 9(2), 233255.

Clark, R. C., Nguyen, F., \& Sweller, J. (2006). Efficiency in learning: Evidencebased guidelines to manage cognitive load. San Francisco: Pfeiffer.

Fraser, K., Ma, I., Teteris, E., Baxter, H., Wright, B, \& McLoughlin, K. (2012). Emotions, cognitive load, and learning outcomes during simulation training. Medical Education. 46. 1055-1062. doi: 10.1111/j.1365-2923.2012.04355.x.

Frenzel, A. C., Pekrun, R, \& Goetz, T. (2007). Girls and mathematics-A "hopeless" issue? A control-value approach to gender differences in emotions towards mathematics. European Journal of Psychology of Education, 22, 497-514.

Hu, L., \& Bentler, P. M. (1999). Cutoff criteria for fit indexes in covariance structure analysis: Conventional criteria versus new alternatives. Structural Equation Modelling 6(1), 1-55.

Kalyuga, S. (2009). Managing cognitive load in adaptive multimedia learning. Hershey: Information Science Reference.

Leppink, J., Paas, F., Gog, T., Vleuten, C. P. M., \& Merrienboer, J. J. G. (2014). Effects of pairs of problems and examples on task performance and different types of cognitive load. Learning and Instruction. 30, 32-42. doi: 10.1016/j.learninstruc.2013.12.001.

Luo, W., Ng, P. T., Lee, K., \& Aye, K. M. (2016). Self-efficacy, value, and achievement emotions as mediators 
between parenting practice and homework behavior: A control-value theory perspective. Learning and Individual Differences. doi: 10.1016/ j.lindif.2016.07.017.

MacKinnon, D. (2008). Introduction to statistical mediation analysis. New York, NY: Lawrence Erlbaum Associates.

Marchand, G. C., \& Gutierrez, A. P. (2012). The role of emotion in the online learning: Comparisons between online and face-to-face learning settings. Internet and Higher Education. 15, 150160.

Pekrun, R. (2006). The control-value theory of achievement emotions: Assumptions, corollaries, and implications for educational research and practice. Educational Psychology Reviews. 18(3). 315-341. doi: 10.1007/s10648-006-90299.

Pekrun, R., Goetz, T., Frenzel, A. C., Barchfeld, P., \& Perry, R. P. (2011). Measuring emotions in students' learning and performance: The achievement emotions questionnaire (AEQ). Contemporary Educational Psychology. 36. 36-48. doi: 10.1016/ j.cedpsych.2010.10.002

Pekrun, R., Goetz, T., Titz, W., \& Perry, R. P. (2002). Academic emotions in students' self-regulated learning and achievement: A program of quantitative and qualitative research. Educational Psychologist, 37, 91-106.
Pintrich, P. R., Smith, D. A., Garcia, T., \& McKeachie, W. J. (1991). A manual for the use of the Motivated Strategies for Learning Questionnaire (MSLQ). Ann Arbor, MI: University of Michigan.

Plass, J. L., Moreno, R., \& Brunken, R., (eds.). (2010). Cognitive load theory. Cambridge: Cambridge University Press.

Preacher, K. J., \& Hayes, A. F. (2008). Asymptotic and resampling strategies for assessing and comparing indirect effects in multiple mediator models. Behavior Research Methods, 40(3), 879891. doi: 10.3758/BRM.40.3.879

Putwain, D., Sander, P., \& Larkin, D. (2013). Academic self-efficacy in study-related skills and behaviours: Relations with learning-related emotions and academic success. British Journal of Educational Psychology, 83, 633-650. doi: 10.1111/j.2044-8279.2012. 02084.x

Sweller, J. (2010a). Element interactivity and intrinsic, extraneous and germane cognitive load. Educational Psychology Review, 22, 123-138. doi: 10.1007/ s10 648-010-9128-5.

Sweller, J. (2010b). Cognitive load theory: Recent theoretical advances. In J.L. Plass, R. Moreno, \& R. Brunken (eds.), Cognitive load theory (p. 29-47). Cambridge: Cambridge University Press. 